\title{
HUBUNGAN SARANA PRASARANA SEKOLAH DENGAN MOTIVASI MENGAJAR GURU DI SMA NEGERI PAMIJAHAN KABUPATEN BOGOR
}

\author{
Wahyu Bagja Sulfemi \\ STKIP Muhammadiyah Bogor \\ Email; wahyubagja@gmail.com
}

\begin{abstract}
Abstrak
Kajian ini membahas tentang hungan sarana prasarana sekolah dengan motivasi mengajar. Penelitian ini bertujuan untuk mengetahui hubungan antara sarana prasarana pendidikan dengan motivasi mengajar di SMA Negeri 1 Pamijahan Bogor. Jenis penelitian ini adalah penelitian kuantitatif, populasi dan sampel penelitian ini adalah guru SMA Negeri 1 Pamijahan Bogor. yang berjumlah 40 orang. Teknik analisis data yang digunakan dalam penelitian ini menggunakan statistika deskriptif dan analisis korelasional dengan menggunakan rumus korelasi product moment dimana variable $\mathrm{X}$ yaitu sarana prasarana pendidikan dan begitu juga dengan variable y yaitu motivasi mengajar. Adapun peroelahan frekuensi variable $\mathrm{X}$ dengan skor tertinggi 122 dan skor terendah 73, diperoleh rata-rata (mean) 98,26; median 98,50 dan modus 86,37. Sedangkan untuk variable Y skor tertinggi 110, skor terendah 70, diperoleh rata-rata (mean) 95,98; median 91,50 dan modus 96,50. Terdapat atau ada hubungan positif antara sarana prasarana pendidikanterhadap motivasi mengajar di SMA Negeri 1 Pamijahan Bogor. Hal ini dibuktikan dengan derajat kebebesan (dk) $=\mathrm{N}-2$ dan $\alpha=0,05$ sebesar $2.000 t_{\text {hitung }}(4,5961)>t_{\text {tabel }}(2000)$ maka koefisien korelasi adalah signifikan $5 \%$ artinya nilai $\mathrm{r}_{\text {hitung }}$ lebih besar dari $\mathrm{r}_{\text {tabel }}$ yakni $0,7016>0,05$ dengan demikian hasilnya dinyatakan signifikan dan hipotesis yang diajukan diterima.
\end{abstract}

Kata Kunci : Sarana prasana, Motivasi, Mengajar, dan Sekolah

\begin{abstract}
This study discusses the relationship between school infrastructure facilities with teaching motivation. This study aims to determine the relationship between educational infrastructure and teaching motivation in SMA 1 Pamijahan, Bogor. This type of research is quantitative research, the population and sample of this study are high school teachers 1 Pamijahan Bogor. which numbered 40 people. The data analysis technique used in this study uses descriptive statistics and correlational analysis using the product-moment correlation formula where variable $\mathrm{x}$ is educational infrastructure and so is the variable $\mathrm{Y}$ which is teaching motivation. The frequency X frequency division with the highest score of 122 and the lowest score of 73 , obtained an average (mean) of 98.26; median 98.50 and 86.37 mode. As for the variable y, the highest score is 110, the lowest score is 70, the average is 95.98; a median of 91.50, and 96.50 modes. There is or there is a positive relationship between educational infrastructure and teaching motivation at SMA 1 Pamijahan Bogor. This is evidenced by the degree of freedom (DK) $=\mathrm{N}-2$ and $\alpha=0.05$ of 2,000 $\mathrm{t}_{\text {arithmetic }}(4.5961)>\mathrm{t}_{\text {table }}$ (2000) then the correlation coefficient is $5 \%$ significant meaning the $r_{\text {count }}$ value is greater than $\mathrm{R}$ table that is $0.7016>$ 0.05 thus the results are declared significant and the proposed hypothesis is accepted.
\end{abstract}

Keywords: Motivation, Teaching, and School 


\section{PENDAHULUAN}

Pendidikan merupakan bagian penting dari proses pembangunan nasional yang ikut menentukan pertumbuhan ekonomi suatu negara. Pendidikan juga merupakan investasi dalam pengembangan sumber daya manusia [1]. Oleh karena itu urgensi peningkatan dan pengembangan sumber daya manusia secara berkelanjutan dijadikan salah satu kebijakan peningkatan mutu pendidikan. Peningkatan kualitas pendidikan merupakan proses yang integral dengan proses peningkatan sumber daya manusia [2], [3].

Dalam Undang-undang Republik Indonesia No. 20 Tahun 2003 tentang Sistem Pendidikan Nasional khususnya pasal yang ke-3 telah dinyatakan bahwa fungsi pendidikan nasional adalah mengembangkan kemampuan dan membentuk watak serta peradaban bangsa yang bermartabat dalam rangka mencerdaskan kehidupan bangsa, bertujuan untuk berkembangnya potensi peserta didik agar menjadi manusia yang beriman dan bertaqwa kepada Tuhan Yang Maha Esa, sehat, berilmu, cakap, kreatif, mandiri, dan menjadi warga negara yang demokratis dan bertanggung jawab [4].

Menyadari pentingnya peningkatan kualitas sumber daya manusia, maka pemerintah bersama-sama kalangan swasta telah dan terus berupaya mewujudkan amanat tersebut melalui berbagai usaha pembangunan bidang pendidikan, seperti pembangunan sarana dan prasarana pendidikan. pengembangan dan pengadaan materi ajar, serta berbagai pelatihan dan penataran bagi guru dan tenaga kependidikan lainnya [5]. Dalam rangka meningkatkan kualitas pendidikan ini maka guru perlu memiliki motivasi yang tinggi dalam mengajar. Karena selain dapat meningkatkan kualitas peserta didik, guru yang memiliki motivasi tinggi tentulah dapat menjadi motivator bagi siswanya. Tidak dapat dipungkiri bahwa guru adalah sutradara pembelajaran, meski guru bukan satu-satunya sumber belajar, namun guru memegang peranan penting dalam proses pembelajaran [6]. Menurut Rusyan, Tebjanastisna, dan Anuraga, motivasi mengajar guru mencakup empat dimensi yaitu; 1) motivasi guru dalam membuat perencanaan pengajaran, 2) motivasi guru dalam melakukan proses pengajaran, 3) motivasi guru dalam melakukan penilaian pengajaran, 4) motivasi guru dalam meningkatkan prestasi belajar siswa. [7]

Sebagai seorang guru sudah sepatutnya menyadari apa yang sebaiknya dilakukan untuk menciptkan kondisi pembelajaran yang dapat mengantarkan anak didik ke tujuan. Disni tentu saja tugas guru berusaha menciptakan suasana belajar yang menggairahkan dan menyenangkan bagi semua anak didik. Suasana belajar yang tidak menggairahkan dan menyenangkan bagi anak didik biasanya lebih mendatangkan kegiatan pengajaran yang kurang harmonis. Anak didik gelisah duduk 
berlama-lama di kursi mereka masing-masing. Kondisi ini tentu menjadi kendala yang serius bagi tercapainya tujuan pengajaran [8]

Seorang guru diharapkan dapat tampil profesional dalam menjalankan tugasnya, karena usaha yang maksimal akan menjadi bagian penting dalam proses pengajaran. Adapun salah satu faktor penunjang yang paling utama untuk mencapai profesionalisme dalam suatu pengajaran adalah adanya motivasi yang harus dimiliki oleh setiap pribadi yang bersangkutan, karena berdasarkan adanya motivasi mengajar maka akan timbul dalam diri seseorang rasa cinta terhadap profesi yang diembannya, sehingga dapat melahirkan hasil yang maksimal bagi prestasi belajar siswa [9]

Berdasarkan Undang-Undang No. 14 Tahun 2005 tentang Guru dan Dosen profesionalisme guru atau guru profesional adalah pekerjaan yang dilakukan oleh seseorang yang menjadi sumber penghasilan kehidupan yang memerlukan keahlian, kemahiran, atau kecakapan yang memenuhi standar mutu atau norma tertentu serta memerlukan pendidikan profesi [10], [13]. Untuk menjadikan guru profesional diperlukan pendidikan formal dari setiap jenjang pendidikan.

Undang-Undang tersebut merupakan sebuah perjuangan sekaligus komitmen untuk meningakatkan kualitas guru yaitu kualifikasi akademik dan kompetensi profesi pendidik sebagai agen pembelajaran. Kualifikasi akademik diperoleh melalui pendidikan tinggi program sarjana (S1) atau D4. Sedangkan kompetensi profesi pendidik meliputi kompetensi pedagogik, kompetensi kepribadian, kompetensi profesional dan kompetensi sosial. Dengan sertifikat profesi, yang diperoleh setelah melalui uji sertifikasi, maka seorang guru berhak mendapat tunjangan profesi sebesar 1 bulan gaji pokok. Intinya, Undang-Undang Guru dan Dosen adalah upaya meningkatkan kualitas kompetensi guru seiring dengan peningkatan kesejahteraan mereka [11].

Mengingat sarana dan prasarana merupakan salah satu faktor penentuan terhadap prestasi belajar siswa, maka persyaratan dan penggunaan sarana pembelajaran harus mengacu pada tujuan pembelajaran, metode, penilaian minat siswa dan kemampuan guru. Kebutuhan sarana dan prasarana pendidikan dalam pembelajaran pendidikan jasmani adalah sangat vital artinya bahwa pembelajaran pendidikan jasmani harus menggunakan sarana dan prasarana yang sesuai dengan kebutuhan dan cara mengontrol ataupun cara pakainya. Sehingga sarana dan prasarana tersebut haruslah ada dalam setiap pembelajaran. Sarana dan prasarana juga harus memenuhi syarat agar tercipta proses pembelajaran secara efektif [12],[15].

Penggunaan sarana pembelajaran dilakukan secara efektif dan efisien dengan mengacu pada proses belajar mengajar di sekolah dan sejauh pihak sekolah belum memiliki sarana pembelajaran yang memadai dilakukan berbagai upaya untuk mengatasinya. Pada umumnya sekolah-sekolah 
terutama yang berada di daerah pelosok sangat membutuhkan atau kekurangan sarana pembelajaran yang memadai. Sementara di sisi lain pemerintah dalam hal ini dinas pendidikan tidak berdaya dengan banyaknya pengajuan penambahan maupun perbaikan sarana pembelajaran yang ada mengingat terbatasnya anggaran yang tersedia [13].

Dengan kenyataan sarana pembelajaran yang ada seperti di atas sementara sistem sekolah yang ada dituntut untuk menghasilkan lulusan yang berprestasi (bermutu) dan dapat melanjutkan ke jenjang sekolah yang lebih tinggi. Sementara para pelaksana di lapangan dalam hal ini guru harus berupaya mencari berbagai alternatif sebagai solusi. Banyak sekolah yang sukses mengatasi masalah tersebut tetapi tidak sedikit sekolah dasar yang akhirnya gagal karena para gurunya tidak mampu mengatasi kendala sarana pembelajaran tersebut. Mungkin juga perhatian masyarakat di sekitarnya kurang bahkan tidak peduli dengan kondisi tersebut.

Motivasi mengajar guru khususnya di SMA Negeri Pamijahan 01 Kabupaten Bogor belum terlihat signifikan. Hal tersebut dapat disebabkan oleh beberapa faktor, salah satunya adalah masih terdapat guru yang belum memiliki sertifikat profesi sebagai guru profesional. Oleha karena itu, diperlukan adanya kajian mengenai permasalahan tersebut melalui sebuah kajian.

\section{KAJIAN LITERATUR}

\section{Pengertian Sarana dan Prasarana Pembelajaran}

Sarana pendidikan adalah barang atau benda bergerak yang dapat dipakai sebagai alat dalam pelaksanaan tugas dan fungsi unit kerja pendidikan. Contoh: mobil, computer, pulpen, kertas, tinta printer, dan lain-lain. Prasarana pendidikan adalah barang atau benda tidak bergerak yang dapat menunjang atau mendukung pelaksanaan tugas dan fungsi unit kerja pendidikan. [16]

Sarana dan prasarana sekolah adalah semua benda bergerak maupun tidak bergerak yang diperlukan untuk menunjang penyelenggaraan proses belajar mengajar pada lembaga pendidikan sekolah baik secara langsung maupun tidak langsung. Secara khusus dapat dibedakan antara sarana pendidikan dan prasarana pendidikan. Sarana sekolah adalah meliputi semua barang serta perlengkapan yang digunakan selama berlangsungnya proses pendidikan di sekolah. Prasarana sekolah adalah semua komponen yang secara tidak langsung menunjang jalannya proses belajar mengajar atau semua fasilitas yang ada sebelum adanya sarana di sekolah seperti: jalan menuju ke sekolah, halaman, dan lain-lain [17].[18]

Peraturan Pemerintah Nomor 32 Tahun 2013, Bab II Pasal 2 menyebutkan bahwa Lingkungan Standar Nasional Pendidikan salah satunya yaitu standar sarana dan prasarana. Ayat dari 
Pasal 24 PP tersebut menyatakan sebagai berikut: 1) Setiap satuan pendidikan wajib memiliki sarana yang meliputi perabot, peralatan pendidikan, media pendidikan, buku, dan sumber belajar lainnya, bahan habis pakai, serta perlengkapan lain yang diperlukan untuk menunjang proses pembelajaran yang teratur dan berkelnjutan. 2) Setiap satuan pendidikan wajib memiliki prasarana yang meliputi lahan, ruang kelas, ruang pimpinan satuan pendidikan, ruang pendidik, ruang tata usaha, ruang perpustakaan, ruang laboratorium, ruang bengkel kerja, ruang unit produksi, ruang kantin, instalasi daya dan jasa, tempat berolahraga, tempat beribadah, tempat bermin, tempat berkreasi, dan ruang atau tempat lain yang diperlukan untuk menunjang proses pembelajaran yang teratur dan berkelanjutan [16].

Dalam melaksanakan amanat tersebut, diterbitkan Peraturan Menteri Pendidikan Nasional (Permendiknas) Nomor 24 Tahun 2007 tentang Standar Sarana Prasarana SD/MI, SMP/MTS, dan SMA/MA. Harapannya adalah tujuan pendidikan pada setiap satuan pendidikan yang telah digariskan pada Undangundang Sistem Pendidikan Nasional Nomor 20 Tahun 2003 segera terwujud. Standar sarana dan prasarana adalah standar nasional pendidikan yang berkaitan dengan kriteria minimal tentang ruang belajar, tempat berolahraga, tempat beribadah, perpustakaan, laboratorium, bengkel kerja, tempat bermain, tempat berkreasi, dan berekreasi, serta sumber belajar lain yang diperlukan untuk menunjang proses pembelajaran, termasuk penggunaan teknologi informasi dan komunikasi [23].

Sekolah sebagai prganisasi kerja diselenggarakan oleh sejumlah personal dalam bentuk kerjasma untuk mencapai tujuan institusional masing-masimg. Kerja sama itu meliputi selurih kegiatan, baik yang bersifat kurikuler maupun ekstra kurikuler termasuk juga kegiatan-kegiatan non edukatif. Untuk melaksanakan kegiatan-kegiatan itu diperlukan berbagai alat kelengkapan. Alat kelengkapan itu harus berdaya guna bagi pencapaian tujuan pendidikan. Beberapa alat kelengkapan sekolah tersebut diantaranya adalah: 1) Perpustakaan Sekolah/Kelas. Perpustakaan merupakan alat kelengkapan yang langsung berhubungan dengan mutu pendidikan dalam rangka mencapai tujuannya, karena mempengaruhi efisiensi proses belajar mengajar. Perpustakaan memungkinkan guru, murid, dan petugas lainnya memperoleh kesempatan memperluas dan memperdalam pengetahuan dan pandangan masingmasing. 2) Laboratorium Sekolah Untuk memberikan kesempatan yang luas bagi guru dan murid mempelajari ilmu pengetahuan melalui pengalaman langsung diperlukan laboratoriun sekolah. Laboratorium memungkinkan proses belajar mengajar tidak sekedar berlangsung secara teoritis dan verbalitas, karena guru dan murid dapat melakukan berbagai percobaan, baik dalam rangka menguji kebenaran teori yang diketahuinya maupun untuk 
menemukan sendiri hal-hal baru. 3) Badan Pembantu Penyelenggaraan Pendidikan (BP3). Untuk membantu petugas kependidikan di sekolah agar tugastugasnya dapat diselenggarakan secara efisien perlu dibentuk BP3 yang anggota-anggotanya terdiri dari orang tua murid dan pemuka-pemuka masyarakat setempat. Badan ini berada di luar struktur formal sebuah sekilah, akan tetapi harus diberi fungsi yang tepat dalam menghimpun potensi di masyarakat agar dapat dimanfaatkan bagi perkembangan sekolah. 4)Bagian atau Pusat Pemgembangan Alat Pengajaran Perkembangan dan kemajuan erat kaitannya dengan perkembangan dan kemajuan ilmu pengetahuan dan teknologi, yang tidak saja berpengaruh pada proses belajar mengajar secara metodologis dan isi pendidikan akan tetapi juga dirasakan pengaruhnya terhadap media pendidikan, khususnya terhadap alat bantu dalam melaksanakan proses belajar mengajar yang efektif. 5) Usaha Kesehatan Sekolah Usaha kesehatan murid dan personal lainnya sangat besar pengaruhnya terhadap situasi belajar mengajar di sekolah. Untuk itu maka perlu dibentuk suatu badan yang disebut Usaha Kesehatan Sekolah atau UKS 6) Koordinator Bidang dalam Pelaksanaan Kurikulum. Agar semua kegiatan terarah dan saling isi mengisi kerap kali perlu dibentuk Koordinator untuk beberapa jenis kegiatan yang memiliki kesamaan kepentingan. Koordinator bidang yang dapat dibentuk antara lain adalah: a.) Koordinator Bidang Studi b.) Koordinator Olah Raga c.) Koordinator Kesenian d.) Koordinator Pembinaan Mental dan Spiritual e.) Koordinator Bidang Kewanitaan f.) Koordinator Bimbingan dan Penyuluhan. 7) Cafetaria atau Warung Sekolah. Pada jam-jam tertentu para siswa mendapat kesempatan beristirahat untuk bermain-main di luar kelas. Kesempatan itu sering dipergunakan untuk mengatasi rasa lapar dan haus dengan menikmati makanan dan minuman yang dibawa dari rumah atau dibeli di warung yang diselenggarakan oleh sekolah atau masyarakat sekitar. 8) Koperasi Sekolah Usaha lain yang dapat dikembangkan disekolah untuk meningkatkan kesejahteraan guru dan murid yang langsung atau tidak langsung berpengaruh pada realisasi proses belajar mengajar adalah koperasi sekolah. Penyelenggaraan koperasi sekolah dapat dilakukan oleh murid-murid dengan bimbingan guru atau oleh petugas khusus yang ditunjuk. 9). Organisasi Murid Dikalangan muridmurid perlu dibentuk suatu organisasi yang bertugas untuk merancang dan melaksanakan berbagai kegiatan dan menyelesaikan berbagai masalah dengan mendayagunakan kemampuan sendiri. Organisasi ini dengan bimbingan guru coordinator bidang dapat melaksanakan kegiatan kesenian, olah raga, kegiatan social, menerbitkan majalah/bulletin, belajar kelompok dan lain-lain yang berguna bagi perkembangan masing-masing. 10) Pramuka Sekolah Sejalan dengan kegiatan organisasi murid, kegiatan kepramukaan dapat dimanfaatkan juga untuk mengembangkan sifat dan sikap serta ketrampilan memimpin dengan perkembangan sikap sosial dan berbagai aspek 
kepribadian yang lain, yang memungkinkan murid memanfaatkannya setelah menjadi dewasa. 11) Dewan Guru Potensi guru sangat menentukan dalam penyelenggaraan sekolah harus dihimpun agar dapat didayagunakan secara maksimal dalam membantu kepala sekolah melaksanakan kepemimpinannya. Di lingkungan sekolah potensi itu dihimpun dalam badan yang disebut Dewan Guru. 12) Bagian Pengajaran dan Ujian Setiap kepala sekolah memerlukan suatu unit kerja yang dapat membantu pengaturan bagian kurikulum, yang disebut Bagian Pengajaran dan Ujian. Fungsi dari unit kerja ini adalah merencanakan, mengorganisir, mengarahkan, mengkoordinir dan mengawasi pelaksanaan kurikulum sepanjang tahun ajaran. Bentuk-bentuk kegiatannya antara lain: menyusun jadwal pelajaran, merencanakan pembagian tugas guru, mengatur penggunaan local belajar, melaksanakan ulangan dan ujian, mendokumentasikan hasil-hasil ulangan dan ujian, mengumumkan hasilhasil ulangan dan ujian danlain-lain. 13) Tata Usaha Sekolah Kegiatan administrasi perkantoran harus dilaksanakan, tanpa membedakan besar kecilnya sekolah.akan tetapi perlu ditekankan bahwa semakin besar organisasi sekolah maka semakin banyak beban kerja administrasi perkantoran. 14) Bagian Penelitian. Dilingkungan sebuah lembaga sekolah diperlukan pembentukan suatu unit kerja yang secara khusus menangani masalah pengembangan ilmu pengetahuan melalui penelitian. Melalui penelitian yang diselenggarakan oleh badan penelitian ini dapat diharapkan juga berkembang usaha untuk memanfaatkan perkembangan ilmu pengetahuan bagi kesejahteraan hidup bersama atau bermasyarakat. 15) Bagian Pengabdian Masyarakat. Unit ini bertugas merancangkan, mengkoordinir, mengawasi dan mengevaluasi kegiatan-kegiatan pengabdian kepada masyarakat [19].[20].

Secara umum sarana dan prasarana belajar (alat belajar) memiliki berbagai manfaat, di antaranya adalah sebagai berikut : a) Dapat mengurangi pemahaman yang bersifat abstrak. Misalnya, untuk menjelaskan janin yang ada di dalam kandungan, dapat dipergunakan film. b) Dapat menampilkan sesutau yang tidak mungkin dibawa ke dalam kelas. C) Membangkitkan motivasi belajar. D) Dapat mengatur dan mengontrol tempo belajar siswa. E) Memungkinkan siswa berinteraksi langsung dengan sumber belajar [21]. [22]

Dapat disimpulkan jika dilihat dari makna per kata, sarana belajar merupakan segala peralatan dan perlengkapan yang secara langsung dipergunakan dalam proses belajar mengajar, seperti gedung, ruang kelas, meja, kursi, serta media pengajaran. Sedangkan, prasarana belajar adalah fasilitas yang secara tidak langsung menunjang jalannya proses pengajaran, seperti halaman, kebun, taman sekolah, jalan menuju sekolah dan lain sebagainya. Jadi kesimpulan dari pengertian sarana dan prasarana 
belajar adalah semua fasilitas yang menunjang proses belajar mengajar di sekolah, baik yang digunakan secara langsung maupun tidak langsung.

\section{Motivasi pengajar}

Menurut Dimyati dan Mudjiono "Motivasi adalah dorongan mental yang menggerakkan perilaku manusia, termasuk perilaku belajar" [24]. Menurut Uno istilah "Motivasi berasal dari kata motif yang berarti kekuatan yang terdapat dalam diri individu, yang menyebabkan individu tersebut bertindak atau berbuat" [25]. Menurut Uno motif sendiri di bedakan menjadi 2 (dua) macam yaitu: Pertama. Motivasi Intrinsik. Motivasi intrinsik timbulnya tidak memerlukan rangsangan dari luar karena memang telah ada dalam diri individu sendiri, yaitu sesuai atau sejalan dengan kebutuhannya. Motivasi yang terkait dengan pemaknaan dan peranan kognisi lebih merupakan motivasi intrinsik, yaitu motivasi yang muncul dari dalam, seperti minat atau keingin tahuan (curiosity) [33], sehingga seseorang tidak lagi termotivasi oleh bentuk-bentuk insentif atau hukuman. Konsep motivasi intrinsik mengidentifikasikan tingkah laku seseorang yang merasa senang terhadap sesuatu; apabila ia menyenangi kegiatan itu, maka termotivasi untuk melakukan kegiatan tersebut. Jika seseorang menghadapi tantangan, dan ia merasa yakin dirinya mampu, maka biasanya orang tersebut akan mencoba melakukan kegiatan tersebut. Pengaturan diri (self regulation) merupakan bentuk tertinggi penggunaan kognisi. [25]

Kedua, Motivasi Ekstrinsik. Motivasi ekstrinsik timbul karena adanya rangsangan dari luar individu, misalnya dalam bidang pendidikan terdapat minat yang positif terhadap kegiatan pendidikan timbul karena melihat manfaatnya. Berikut beberapa hal yang dapat menimbulkan motivasi ekstrinsik, antara lain: 1) pendidikan memerlukan anak didiknya, sebagai manusia yang berpribadi, menghargai pendapatnya, pikirannya, perasaannya, maupun kenyakinannya; 2) pendidikan menggunakan berbagai metode dalam melaksanakan kegiatan pendidikannya.

Sedangkan motivasi ekstrinsik berisi: (a) penyesuaian tugas dengan minat, (b) perencanaan yang penuh variasi, (c) respon siswa, (d) kesempatan peserta didik yang aktif, (e) kesempatan peserta didik untuk menyesuaikan tugas pekerjaannya, dan (f) adanya kegiatan yang menarik dalam belajar. Motif intrinsik lebih kuat dari motif ekstrinsik. Oleh karena itu pendidikan harus berusaha menimbulkan motif intrinsik dengan menumbuhkan dan mengembangkan minat peserta didik terhadap bidang-bidang studi yang relevan [26].[28]

Dapat disimpulkan bahwa motivasi adalah dorongan internal dan eksternal dalam diri seseorang untuk mengadakan perubahan tingkah laku, yang mempunyai indikator sebagai berikut: 1) 
adanya hasrat dan keinginan untuk melakukan kegiatan, 2) adanya dorongan dan kebutuhan melakukan kegiatan, 3) adanya harapan dan cita-cita, 4) adanya lingkungan yang baik, dan 5) adanya kegiatan yang menarik. [27]

Menurut Hamalik mendefinisikan "Motivasi adalah perubahan energi dalam diri (pribadi) seseorang yang ditandai dengan timbulnya perasaan dan reaksi untuk mencapai tujuan”.[29] Sedangkan fungsi motivasi menurut Hamalik meliputi sebagai berikut: a) Mendorong timbulnya kelakuan atau suatu perbuatan. Tanpa motivasi maka tidak akan timbul sesuatu perbuatan seperti belajar.b) Motivasi berfungsi sebagai pengaruh. Artinya mengarahkan perbuatan kepencapaian tujuan yang diinginkan. C) Motivasi berfungsi sebagai penggerak. Besar kecilnya motivasi akan menetukan cepat atau lambatnya suatu pekerjaan [29].

Sikap positif yang diperlihatkan pengajar dan asisten terhadap mata ajar yang disajikan pada siswa dan terhadap metode pengajaran yang digunakan, dapat memengaruhi motivasi dan sikap siswa terhadap minat bahan ajar. Apabila siswa merasakan atau benar-benar melihat ungkapan atau sikap positif seperti itu, siswa akan cenderung bertingkah laku positif. Hasilnya dapat sangat mendukung keberhasilan program pengajaran tersebut.[30] Dimyati dan Mudjiono mengatakan bahwa "Dengan pembuatan persiapan mengajar, pelaksanaan belajar-mengajar, maka guru menguatkan motivasi belajar siswa". [24] Sehubungan hal tersebut, perlu ditegaskan bahwa prinsip mengajar adalah mempermudah dan memberikan motivasi kegiatan belajar. Sehingga guru sebagai pengajar memiliki tugas memberikan fasilitas atau kemudahan bagi suatu kegiatan belajar subjek belajar/siswa.

Keberhasilan suatu organisasi atau lembaga dipengaruhi oleh berbagai faktor, baik faktor yang datang dari dalam maupun yang datang dari lingkungan. Dari berbagai faktor tersebut, motivasi merupakan suatu faktor yang cukup dominan dan dapat menggerakkan faktor-faktor lain kearah efektivitas kerja. Dalam hal tertentu motivasi sering disamakan dengan mesin dan kemudi mobil, yang berfungsi sebagai penggerak dan pengarah.

Setiap pegawai memiliki karakteristik khusus, yang satu sama lain berbeda. Perbedaan pegawai tidak hanya dalam bentuk fisik, tetapi juga dalam psikisnya, misalnya motivasi. Oleh karena itu, untuk meningkatkan kinerja, perlu diupayakan untuk membangkitkan motivasi para pegawai dan faktor-faktor lain yang mempengaruhinya. Motivasi merupakan salah satu faktor yang turut menentukan kefektifan kerja. Menurut Callahan dan Clark yang dikutip oleh Admin mengemukakan bahwa "Motivasi adalah tenaga pendorong atau penarik yang menyebabkan adanya tingkah laku ke arah tujuan tertentu. Mengacu pada pendapat tersebut, dapat dikemukakan bahwa motivasi merupakan suatu bagian yang sangat penting dalam suatu lembaga". Para pegawai akan bekerja 
dengan sungguh-sungguh apabila memiliki motivasi yang tinggi. Apabila para pegawai memiliki motivasi positif, ia akan memperlihatkan minat, mempunyai perhatian, dan ingin ikut serta dalam tugas atau kegiatan. Dengan kata lain, seorang pegawai akan melakukan semua pekerjaannya dengan baik apabila ada faktor pendorong (motivasi). Motivasi merupakan bagian penting dalam setiap kegiatan, tanpa motivasi tidak ada kegiatan yang nyata. Guru dapat mempunyai motivasi yang tinggi dalam melaksanakan tugas mengajar apabila didukung dengan latar belakang profesional yang baik dan didukung oleh sarana dan prasarana serta hubungan yang terjalin secara harmonis antara semua personil yang ada. Demikian juga guru dalam proses belajar mengajar harus memiliki kemampuan tersendiri guna mencapai harapan yang di cita-citakan dalam melaksanakan pendidikan pada umumnya dan proses belajar mengajar pada khususnya.[31]

Berdasarkan kepada uraian di atas, maka dapat disimpulkan bahwa, motivasi mengajar merupakan elemen yang sangat penting bagi seorang guru dalam melaksanakan tugasnya sebagai tenaga pendidik. Dengan adanya motivasi dalam mengajar, maka diharapkan guru dapat melaksanakan tugasnya dengan baik dan mencapai cita-cita yang diharapkan.

\section{METODOLOGI PENELITIAN}

Penelitian ini dilakukan di SMA Negeri 1 Pamijahan Kabupaten Bogor. Untuk memperoleh data dan informasi yang diperlukan guna memecahkan masalah dan mencapai tujuan, maka peneliti membutuhkan sumber data yang disebut populasi. Hal ini sejalan dengan pendapat Sugiyono, bahwa populasi adalah keseluruhan objek penelitian yang dapat terdiri dari manusia, benda-benda, hewan, tumbuh-tumbuhan, gejala-gejala, nilai test atau peristiwa-peristiwa sebagai sumber data yang memiliki karaktersitik tertentu di dalam suatu penelitian.[32]

Setelah populasi ditetapkan, selanjutnya ditentukan sampel agar segera dapat dilakukan pengumpulan data. Pengambilan sampel dilakukan melalui prosedur proportional dan random sampling. Teknik proporsional digunakan untuk menentukan jumlah sampel dari masing-masing sekolah, sedangkan teknik random sampling yang digunakan adalah simple random sampling yakni sampel yang diambil dengan menggunakan undian terhadap semua populasi pada suatu sekolah.

Pengumpulan data penelitian ini adalah dengan menggunakan angket. Angket berarti sejumlah pertanyaan atau pernyataan yang disampaikan kepada responden untuk menyatakan, mengecek dan meminta pendapat tentang sesuatu hal yang akan diteliti. Alasan menggunakan angket adalah untuk mengungkap pendapat tentang kompetensi profesionalisme guru dan kinerja mengajar 
guru dalam menyusun rencana pelajaran, melaksanakan pelajaran (proses belajar mengajar) dan mengevaluasi pelajaran.

Sebelum membuat angket peneliti menjabarkan kisi-kisi penelitian variabel dan terdapat indikator penelitian, maksudnya adalah untuk menjadikan pedoman dalam pembuatan angket penelitian. Menurut para ahli agar responden dapat memberikan respon terhadap pertanyaan dengan menggunakan model Skala Likert.

Penggunaan skala Likert agar responden dapat memberikan respon terhadap statement dengan memberikan salah satu jawaban dari lima alternatif jawaban pada masing-masing statement pertanyaaan. Tiap-tiap respon diasosiasikan dengan suatu nilai dan nilai individual ditentukan dengan sejumlah nilai masing-masing statement. Misalnya untuk nilai positif dimulai dari, selalu $=5$, sering $=$ 4, kadang-kadang $=3$, jarang $=2$, tidak pernah $=1$.

Uji validitas pada instrumen ditempuh dengan langkah menentukkan butir soal yang valid dan tidak valid. Pengujian dilakukan dengan menggunakan korelasi Pearson Product Moment. Kriteria penilaian validitas dengan membandingkan nilai r-hitung dengan r-tabel pada taraf nyata 0,05. Apabila r-hitung $>$ r-tabel, maka dinyatakan valid.

\section{HASIL DAN PEMBAHASAN}

Penelitian ini bertujuan untuk mengetahui hubungan antara kompetensi profesionlisme guru dengan motivasi mengajar guru di SMA Negeri Pamijahan 01 Kabupaten Bogor. Pada bagian ini akan diuraikan mengenai data hasil studi lapangan berupa data tentang hubungan antara sarana prasarana sekolah dengan motivasi mengajar guru dengan menggunakan kuesioner yang disebarkan kepada 40 orang responden, yaitu guru-guru di SMA Negeri Pamijahan 01 Kabupaten Bogor

Sebelum kuesioner digunakan dalam analisis penelitian ini, sebelumnya telah dilakukan uji validitas dan reliabilitas. Instrumen penelitian ini terdiri dari 30 item pertanyaan untuk variabel sarana prasarana sekolah dan 30 item pertanyaan untuk variabel motivasi mengajar guru. Adapun hasil uji validitas tersebut menunjukkan bahwa untuk item pertanyaan kompetensi profesionalisme guru, dari 30 pertanyaan terdapat 25 pertanyaan yang valid. Sedangkan untuk item pertanyaan motivasi mengajar guru, dari 30 pertanyaan terdapat 23 pertanyaan yang valid.

\section{Deskripsi Tabulasi Data Variabel Sarana Prasarana Sekolah}


Berdasarkan hasil penyebaran kuesioner penelitian kepada 40 orang responden pada SMA Negeri Pamijahan 01 Kabupaten Bogor, diketahui bahwa hasil tabulasi data kuesioner untuk variabel sarana prasarana sekolah adalah sebagai berikut.

Tabel 1

Distribusi Frekuensi Sarana Prasana Sekolah

\begin{tabular}{|c|c|c|c|c|c|c|c|}
\hline Kelas & $\begin{array}{c}\text { Interval } \\
\text { Kelas }\end{array}$ & $\mathbf{f}_{\mathbf{i}}$ & $\mathbf{x}_{\mathbf{i}}$ & $\mathbf{x}_{\mathbf{i}}{ }^{2}$ & $\mathbf{f}_{\mathbf{i}} \mathbf{x}_{\mathbf{i}}$ & $\mathbf{f}_{\mathbf{i}} \cdot \mathbf{x}_{\mathbf{i}}{ }^{2}$ & $\mathbf{f r}$ \\
\hline 1 & $73-79$ & 1 & 76 & 5.776 & 76 & 5.776 & 2,5 \\
\hline 2 & $80-86$ & 5 & 83 & 6.889 & 415 & 34.445 & 12,5 \\
\hline 3 & $87-93$ & 4 & 90 & 8.100 & 360 & 32.400 & 10,0 \\
\hline 4 & $94-100$ & 8 & 97 & 9.409 & 776 & 75.272 & 20,0 \\
\hline 5 & $101-107$ & 8 & 104 & 10.816 & 832 & 86.528 & 20,0 \\
\hline 6 & $108-114$ & 10 & 111 & 12.321 & 1.110 & 123.210 & 25,0 \\
\hline 7 & $115-121$ & 4 & 118 & 13.924 & 472 & 55.696 & 10,0 \\
\hline \multicolumn{2}{|c|}{ Jumlah } & $\mathbf{4 0}$ & $\mathbf{6 7 9}$ & $\mathbf{6 7 . 2 3 5}$ & $\mathbf{4 . 0 4 1}$ & $\mathbf{4 1 3 . 3 2 7}$ & $\mathbf{1 0 0}$ \\
\hline
\end{tabular}

Sumber: Data diolah.

Berdasarkan data pada Tabel 2 di atas, hasil tabulasi data dari 40 orang guru pada SMA Negeri Pamijahan 01 Kabupaten Bogor yang menjadi responden dari penelitian ini untuk variabel sarana prasarana sekolah diketahui bahwa skor terendah adalah 73 dan skor tertinggi 121, jangkauan sebesar 48, rata-rata skor 101,03, median (nilai tengah) sebesar 102,25, dan modus (nilai paling sering muncul) sebesar 109,25. Pada tabel di atas terlihat pula bahwa, skor terbanyak muncul berada pada kelas 6 dengan frekuensi sebanyak 10 atau 25\%. Hal tersebut menunjukkan bahwa, secara umum sarana prasarana sekolah pada SMA Negeri Pamijahan 01 Kabupaten Bogor dapat dinilai baik. Selanjutnya deskripsi data mengenai variabel sarana prasarana sekolah tersebut dapat pula dilihat dalam bentuk histogram seperti pada Gambar 1. 


\section{Gambar 1}

\section{Histogram Skor Sarana Prasarana Sekolah}

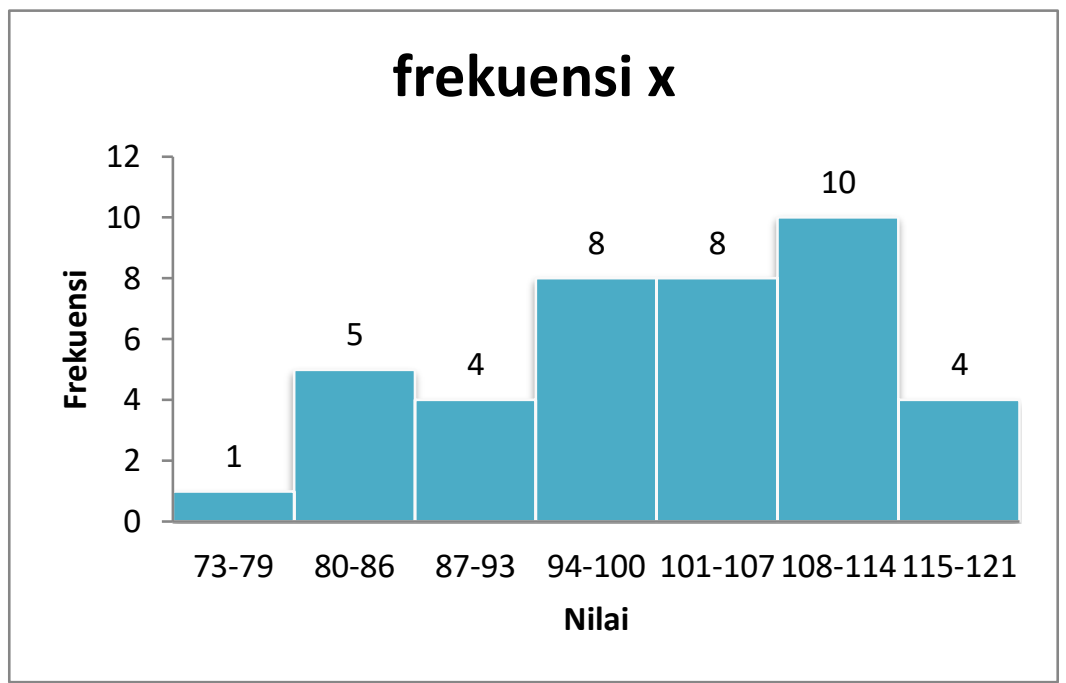

Sumber : Data diolah.

\section{Deskripsi Tabulasi Data Variabel Motivasi Mengajar Guru}

Berdasarkan hasil penyebaran kuesioner penelitian kepada 40 orang responden pada SMA Negeri Pamijahan 01 Kabupaten Bogor, diketahui bahwa hasil tabulasi data kuesioner untuk variabel motivasi mengajar guru adalah sebagai berikut.

Tabel 2

Distribusi Frekuensi Data Motivasi Mengajar Guru

\begin{tabular}{|c|c|c|c|c|c|c|c|}
\hline Kelas & $\begin{array}{c}\text { Interval } \\
\text { Kelas }\end{array}$ & $\mathbf{f}_{\mathbf{i}}$ & $\mathbf{x}_{\mathbf{i}}$ & $\mathbf{x}_{\mathbf{i}}{ }^{2}$ & $\mathbf{f}_{\mathbf{i}} \mathbf{x}_{\mathbf{i}}$ & $\mathbf{f}_{\mathbf{i}} \cdot \mathbf{x}_{\mathbf{i}}{ }^{2}$ & Fr (\%) \\
\hline 1 & $75-80$ & 6 & 77,5 & $6.006,25$ & 465,00 & $36.037,50$ & 15,00 \\
\hline 2 & $81-86$ & 5 & 83,5 & $6.972,25$ & 417,50 & $34.861,25$ & 12,50 \\
\hline 3 & $87-92$ & 6 & 89,5 & $8.010,25$ & 537,00 & $48.061,50$ & 15,00 \\
\hline 4 & $93-98$ & 7 & 95,5 & $9.120,25$ & 668,50 & $63.841,75$ & 17,50 \\
\hline 5 & $99-104$ & 8 & 101,5 & $10.302,25$ & 812,00 & $82.418,00$ & 20,00 \\
\hline 6 & $105-110$ & 6 & 107,5 & $11.556,25$ & 645,00 & $69.337,50$ & 15,00 \\
\hline 7 & $111-116$ & 2 & 113,5 & $12.882,25$ & 227,00 & $25.764,50$ & 5,00 \\
\hline \multicolumn{2}{|c|}{ Jumlah } & $\mathbf{4 0}$ & $\mathbf{6 6 8 , 5 0}$ & $\mathbf{6 4 . 8 4 9 , 7 5}$ & $\mathbf{3 . 7 7 2 , 0 0}$ & $\mathbf{3 6 0 . 3 2 2 , 0 0}$ & $\mathbf{1 0 0}$ \\
\hline
\end{tabular}

Sumber: Data diolah.

Berdasarkan data pada Tabel 4.2 tersebut, dapat diketahui bahwa dari 40 orang responden diperoleh skor total minimum sebesar 75 dan skor total responden tertinggi adalah sebesar 116, 
jangkauan atau range sebesar 40, rata-rata skor yang diperoleh adalah sebesar 94,3, median sebesar 95,07, dan modus sebesar 100,5. Dari tabel tersebut terlihat pula, dari 40 orang guru yang menjadi responden penelitian ini nilai terbanyak berada pada kelas interval 5, yaitu dengan frekuensi sebesar 8 atau 20\%. Hasil tersebut menunjukkan bahwa secara umum motivasi mengajar guru pada SMA Negeri Pamijahan 01 Kabupaten Bogor dapat dikatakan baik.

Deskripsi data untuk motivasi mengajar guru disajikan pula dalam bentuk histogram berikut ini.

\section{Gambar 2}

Histogram Skor Motivasi Mengajar Guru

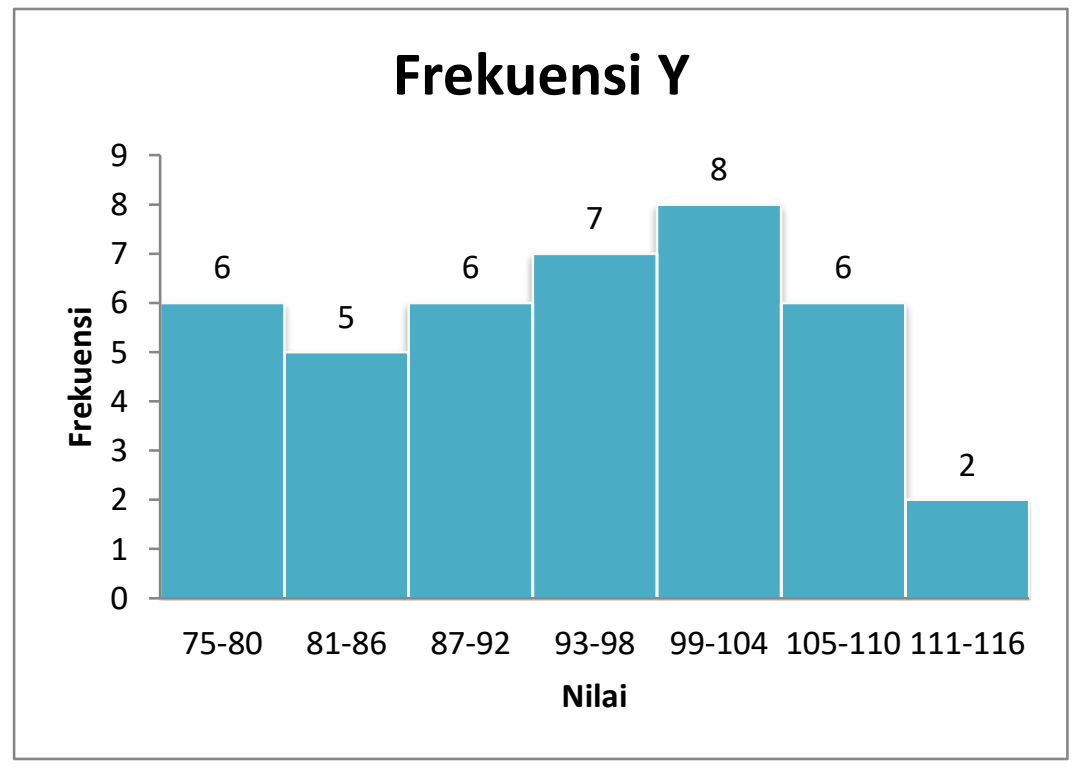

Sumber : Data diolah.

Pengujian korelasional dalam penelitian ini adalah untuk mengetahui bagaimana hubungan antara variabel sarana prasarana sekolah dengan motivasi mengajar guru di SMA Negeri Pamijahan 01 Kabupaten Bogor Kabupaten Bogor. Alat analisis yang digunakan adalah Korelasi Pearson Product Momment. Pengujian tersebut dilakukan dengan bantuan program Microsoft Excel.

Untuk memudahkan peneliti dalam mengolah data dan untuk mengetahui hubungan antara sarana prasarana sekolah dan motivasi mengajar guru pada SMA Negeri Pamijahan 01 Kabupaten Bogor, maka peneliti membuat tabulasi data. Setelah diolah dengan menggunakan rumus korelasi pearson product momment memperoleh hasil bahwa koefisien korelasi untuk hubungan antara kompetens profesionalisme guru dengan motivasi mengajar guru adalah sebesar 85,46\% sedangkan sisanya sebesar 14,54\% dijelaskan oleh variabel lain yang tidak terdefinisi. Dengan demikian, 
berdasarkan hasil penelitian ini dapat dinyatakan bahwa hubungan antara sarana prasarana sekolah dengan motivasi mengajar guru di SMA Negeri Pamijahan 01 Kabupaten Bogor sangat kuat dan berhubungan positif.

Nilai t-hitung yang diperoleh berdasarkan nilai koefisien korelasi tersebut adalah sebesar 10,144. Apabila nilai t-hitung tersebut dibandingkan dengan nilai t-tabel pada taraf nyata 0,05 (5\%) dengan $\mathrm{df}=\mathrm{n}-2$ sebesar 2,0244 ternyata diperoleh kesimpulan t-hitung $>$ t-tabel. Dengan demikian dapat dikatakan bahwa, hubungan antara sarana prasarana sekolah dengan motivasi mengajar guru di SMA Negeri Pamijahan 01 Kabupaten Bogor sangat signifikan dan berbanding lurus.

Interpretasi data yang akan diuraikan berikut ini berdasarkan kepada permasalahan yang mempertanyakan bagaimana gambaran sarana prasarana sekolah di SMA Negeri Pamijahan 01 Kabupaten Bogor, bagaimana gambaran motivasi mengajar guru di SMA Negeri Pamijahan 01 Kabupaten Bogor, dan apakah terdapat hubungan sarana prasarana sekolah terhadap motivasi mengajar guru di SMA Negeri Pamijahan 01 Kabupaten Bogor.

Hasil penelitian ini menunjukkan bahwa, dari 40 orang guru pada SMA Negeri Pamijahan 01 Kabupaten Bogor yang menjadi responden dari penelitian ini untuk variabel sarana prasarana sekolah diketahui bahwa skor terendah adalah 73 dan skor tertinggi 121, jangkauan sebesar 48, ratarata skor 101,03, median (nilai tengah) sebesar 102,25, dan modus (nilai paling sering muncul) sebesar 109,25. Pada tabel di atas terlihat pula bahwa, skor terbanyak muncul berada pada kelas 6 dengan frekuensi sebanyak 10 atau 25\%. Hal tersebut menunjukkan bahwa, secara umum sarana prasarana sekolah pada SMA Negeri Pamijahan 01 Kabupaten Bogor dapat dinilai baik.

Untuk motivasi mengajar guru, hasil penelitian ini membuktikan dari 40 orang responden diperoleh skor total minimum sebesar 75 dan skor total responden tertinggi adalah sebesar 116, jangkauan atau range sebesar 40, rata-rata skor yang diperoleh adalah sebesar 94,3, median sebesar 95,07, dan modus sebesar 100,5. Dari tabel tersebut terlihat pula, dari 40 orang guru yang menjadi responden penelitian ini nilai terbanyak berada pada kelas interval 5, yaitu dengan frekuensi sebesar 8 atau 20\%. Hasil tersebut menunjukkan bahwa secara umum motivasi mengajar guru pada SMA Negeri Pamijahan 01 Kabupaten Bogor dapat dikatakan baik.

Analisis korelasi dengan menggunakan rumus pearson product momment memperoleh hasil bahwa, koefisien korelasi untuk hubungan kompetens profesionalisme guru dengan motivasi mengajar guru adalah sebesar 85,46\% sedangkan sisanya sebesar 14,54\% dijelaskan oleh variabel lain yang tidak terdefinisi. Dengan demikian, berdasarkan hasil penelitian ini dapat dinyatakan bahwa 
hubungan antara sarana prasarana sekolah dengan motivasi mengajar guru di SMA Negeri Pamijahan 01 Kabupaten Bogor sangat kuat dan berhubungan positif.

Nilai t-hitung yang diperoleh berdasarkan nilai koefisien korelasi tersebut adalah sebesar 10,144. Apabila nilai t-hitung tersebut dibandingkan dengan nilai t-tabel pada taraf nyata 0,05 (5\%) dengan $\mathrm{df}=\mathrm{n}-2$ sebesar 2,0244 ternyata diperoleh kesimpulan t-hitung $>\mathrm{t}$-tabel. Dengan demikian dapat dikatakan bahwa, hubungan antara sarana prasarana sekolah dengan motivasi mengajar guru di SMA Negeri Pamijahan 01 Kabupaten Bogor Kabupaten Bogor sangat signifikan dan berbanding lurus.

Hasil analisis korelasi dengan menggunakan rumus pearson's product momment menunjukan nilai koefisien korelasi $\left(\mathrm{r}_{\mathrm{xy}}\right)$ sebesar 0,8546. Nilai tersebut selanjutnya disebut dengan nilai $\mathrm{r}$-hitung. Apabila nilai r-hitung dibandingkan dengan nilai r-tabel pada taraf nyata 0,05 dengan data sebanyak 40 maka diperoleh $\mathrm{df}=38$ adalah sebesar 0,2605 ternyata diperoleh kesimpulan $\mathrm{r}_{\text {hitung }}>\mathrm{r}_{\text {tabel. }}$. Kriteria pengujian hipotesis penelitian ini adalah sebagai berikut :

- Jika $\mathrm{r}_{\text {hitung }}>\mathrm{r}_{\text {tabel, }}$ maka tolak $\mathrm{H}_{0}$

- Jika $\mathrm{r}_{\text {hitung }}<\mathrm{r}_{\text {tabel, }}$, maka tolak $\mathrm{H}_{1}$

$\mathrm{H}_{0} \quad=$ menyatakan tidak terdapat hubungan antara sarana prasarana sekolah dengan motivasi mengajar guru

$\mathrm{H}_{1} \quad=$ menyatakan terdapat hubungan antara sarana prasarana sekolah dengan motivasi mengajar guru.

Berdasarkan hasil analisis korelasi dengan menggunakan product momment, diketahui bahwa, nilai $r_{\text {hitung }}>r_{\text {tabel. }}$. Dengan demikian, dapat dinyatakan bahwa berdasarkan hasil penelitian ini, $\mathrm{H}_{0}$ ditolak dan $\mathrm{H}_{1}$ diterima. Tingkat korelasi yang dihasilkan dari penelitian ini adalah sebesar 0,8546 atau $85,46 \%$ ternyata berada pada kriteria sangat kuat. Artinya bahwa, hubungan antara sarana prasarana sekolah dengan motivasi mengajar guru pada SMA Negeri Pamijahan 01 Kabupaten Bogor Kabupaten Bogor sangat kuat.

\section{KESIMPULAN DAN SARAN}

Berdasarkan kepada hasil penelitian dan perumusan masalah, maka dapat ditarik beberapa kesimpulan dari penelitian ini antara lain sebagai berikut: 1) Sarana prasarana di sekolah SMA Negeri 1 Pamijahan Kabupaten Bogor dinilai baik. Hal tersebut dibuktikan dari 40 orang responden yang merupakan guru, skor terbanyak muncul terdapat pada kelas interval 6 dimana rata-rata skor pada kelas interval tersebut adalah 111 dengan frekuensi sebanyak 10 atau 25\%. 2) Motivasi mengajar guru 
di SMA Negeri 1 Pamijahan Kabupaten Bogor berdasarkan hasil penelitian ini berada dapat dinyatakan baik. Hal tersebut dibuktikan dengan hasil analisis yang menunjukkan bahwa dari 40 orang guru yang menjadi responden penelitian ini nilai terbanyak berada pada kelas interval 5 dimana rata-rata skor pada kelas interval tersebut adalah 101,5 dengan frekuensi sebesar 8 atau 20\%. 3) Hubungan antara sarana prasarana sekolah dengan motivasi mengajar guru di SMA Negeri 1 Pamijahan Kabupaten Bogor berdasarkan hasil penelitian ini dinyatakan sangat kuat dan positif. Hal ini dibuktikan dengan nilai koefisien korelasi product momment $\left(\mathrm{r}_{\text {hitung }}\right)$ yang diperoleh sebesar 0,8546 ternyata lebih besar dari $\mathrm{r}_{\text {tabel }}$ pada taraf nyata 0,05 dengan $\mathrm{df}=38$.

Saran yang dapat peneliti ajukan dalam penelitian ini adalah 1) Kuatnya hubungan antara sarana prasarana pendidikan dengan motivasi mengajar guru menunjukkan bahwa keberhasilan proses kegiatan pembelajaran di SMA Negeri 1 Pamijahan Kabupaten Bogor sangat ditentukkan oleh kedua faktor tersebut. Oleh karena itu, sangat penting bagi Kepala Sekolah dan dinas kabupaten untuk selalu memelihara motivasi mengajar guru melalui peningkatan sarana prasarana sekolah. 2) sarana prasarana sekolah dan motivasi mengajar guru di SMA Negeri 1 Pamijahan Kabupaten Bogor harus terus ditingkatkan hingga seluruh guru yang mengajar pada lembaga pendidikan di SMA Negeri 1 Pamijahan Kabupaten Bogor memiliki kompetensi profesional dan motivasi mengajar yang baik. 3) Penelitian ini masih jauh dari kesempurnaan, karena hanya menganalisa dari dua faktor saja. Oleh karena itu, diharapkan ada penelitian lanjutan dengan menggunakan faktor lainnya yang berhubungan dengan aktivitas guru, karena guru merupakan elemen yang paling utama dalam keberhasilan kegiatan pembelajaran.

\section{Referensi}

[1] Palettei, A. D., \& Sulfemi, Sulfemi, W. B. (2019). Pengaruh Kelompok Kerja Guru (KKG) Terhadap Peningkatan Kompetensi Pedagogik dan Kemampuan Menulis Karya Ilmiah. Jurnal Pendidikan Dasar Indonesia Jurnal Pendidikan Dasar Indonesia (JPDI). 7 (2). 53 - 58. DOI: http://dx.doi.org/10.26737/jpdi.v4i2.1522.

[2] Umaedi, (1999). Manajemen Peningkalan Mutu Berbasis Sekolah. Jakarta: Ditjen Dikdasmen Depdiknas.

[3] Sulfemi, W. B., \& Minati, H. (2018). Meningkatkan Hasil Belajar Peserta Didik Kelas 3 SD Menggunakan Model Picture And Picture dan Media Gambar Seri. JPSD. 4 (2), 228- 242. DOI: http://dx.doi.org/10.30870/jpsd.v4i2.3857

[4] Undang-Undang Republik Indonesia Nomor 20 Tabun 2003 Tentang Sistem Pendidikan Nasional

[5] Sulfemi, W. B. (2018). Pengaruh Disiplin Ibadah Sholat, Lingkungan Sekolah, dan Intelegensi Terhadap Hasil Belajar Peserta Didik Mata Pelajaran Pendidikan Agama Islam. Edukasi: Jurnal Penelitian Pendidikan Agama dan Keagamaan. 16 (2), 166-178. DOI: 10.32729/edukasi.v16i2.474. 
[6] Sulfemi, W. B., \& Kamalia, Y. (2020). Jigsaw Cooperative Learning Model Using Audiovisual Media To Improve Learning Outcomes. JPsd (Jumal Pendidikan Sekolah Dasar). 6 (1), 30-42. DOI: http://dx.doi.org/10.30870/jpsd.v6i1.4919

[7] http://ddayipartikel.blogspot.com/2012/04/pengertian-dan-sejarah-didaktif.html

[8] Sulfemi, W.B., \& Yuliana, D. (2019). Penerapan Model Pembelajaran Discovery Learning Meningkatkan Motivasi Dan Hasil Belajar Pendidikan Kewarganegaraan. Jurnal Rontal Keilmuan Pancasila dan Kewarganegaraan, 5(1), 17-30. Doi: http://dx.doi.org/10.29100/jr.v5i1.1021.

[9] Sulfemi, Wahyu Bagja. (2019). Model Pembelajaran Kooperatif Mind Mapping Berbantu Audio Visual Dalam Meningkatkan Minat, Motivasi dan Hasil Belajar IPS. Jurnal PIPSI Jurnal Pendidikan IPS Indonesia), 4(1), 13-19. DOI: http://dx.doi.org/10.26737/jipips.v4i1.1204

[10] Depdiknas, (2007). "Undang-undang Republik Indonesia Nomor 14 Tahun 2005 Tentang Guru dan Dosen"

[11] Sulfemi, W. B., \& Mayasari, N. (2019). Peranan Model Pembelajaran Value Clarification Technique Berbantuan Media Audio Visual Untuk Meningkatkan Hasil Belajar IPS. Jurnal Pendidikan. 20 (1). 53-68. DOI: https://doi.org/10.33830/jp.v20i1.235.2019

[12] Sulfemi, Wahyu Bagja dan Yuliani, Nunung. (2019). Model Pembelajaran Contextual Teaching And Learning (CTL) Berbantu Media Miniatur Lingkungan Untuk Meningkatkan Hasil Belajar IPS. Edunomic. 7 (2). 73-84. DOI : 10.33603/ejpe.v7i2.1970.

[13] Sulfemi, Wahyu Bagja dan Setianingsih. (2018), Penggunaan Tames Games Tournament (TGT) Dengan Media Kartu Dalam Meningkatkan Hasil Belajar. Journal of Komodo Science Education (JKSE). 1 (1), 1-14. https://www.ejournal.stkipsantupaulus.ac.id/index.php/jkse/article/view/191/180

[14] Sulfemi, Wahyu Bagja. (2019). Manajemen Pendidikan Berbasis Multi Budaya. Bogor : STKIP Muhammadiyah Bogor.

[15] Arsyad, Arsyad dan Sulfemi, Wahyu Bagja. (2018) Metode Role Playing Berbantu Media Audio Visual Pendidikan dalam Meningkatkan Belajar IPS. Jurnal Pendidikan Ilmu Pengetahuan Sosial Indonesia. 3 (2). 41 - 46. DOI: http://dx.doi.org/10.26737/jpipsi.v3i2.1012.

[16] Teguh Triwiyanto, (2015). Pengantar Pendidikan, Jakarta: Bumi Aksara,

[17] Musfiqon dan Andiek Widodo, (2016), Manajemen Sekolah Unggul, Sidoarjo: Nizamia Learning Center.

[18] Sulfemi, Wahyu Bagja dan Nurhasanah. (2018). Penggunaan Metode Demontrasi dan Media Audio Visual Dalam Meningkatkan Hasil Belajar Peserta Didik Mata Pelajaran IPS. Jurnal Pendas Mahakam. $\quad 3 \quad$ (2). 151-158. https://jurnal.fkipuwgm.ac.id/index.php/pendasmahakam/article/view/229

[19] Hadari Nawawi, (1989). Organisasi Sekolah dan Pengelolaan Kelas sebagai Lembaga Pendidikan, Jakarta: Inti Indayu Press.

[20] Sulfemi, Wahyu Bagja. (2018). Manajemen Kurikulum di Sekolah. Bogor : Visi Nusantara Maju

[21] Abudin Nata, (2011). Prespektif Islam Tentang Strategi Pembelajaran, Jakarta: Kencana, 2011.

[22] Sulfemi, Wahyu Bagja., \& Desmiati, Z. (2018). Model Pembelajaran Missouri Mathematics Project Berbantu Media Relief Experience dalam Meningkatkan Hasil Belajar Siswa. PENDAS MAHAKAM: Jurnal Pendidikan Dasar,3(3), 232-245. https://jurnal.fkipuwgm.ac.id/index.php/pendasmahakam/article/view/269/173

[23] Sulfemi, Wahyu Bagja dan Supriyadi, Dede. (2018). Pengaruh Kemampuan Pedagogik Guru dengan Hasil Belajar IPS. Edutecno 17 (1), 1-10.

[24] Dimyati dan Mudjiono, (1999), Belajar dan Pembelajaran, Jakarta: PT. Rineka Cipta.

[25] Uno, Hamzah dan Nina Lamatenggo. (2012). Teknologi Komunikasi dan Informasi Pembelajaran. Bumi Aksara : Jakarta. 
[26] Sulfemi, Wahyu Bagja. (2018). Hubungan Motivasi Belajar Dengan Hasil Belajar IPS Di SMP Kabupaten Bogor. Edutecno 18 (2), 1-8.

[27] Sulfemi, Wahyu Bagja dan Abdul Qodir. (2017). Hubungan Kurikulum 2013 Dengan Motivasi Belajar Peserta Didik Di SMK Pelita Ciampea. Edutecno 17 (2), 1-8.

[28] Sulfemi, Wahyu Bagja. (2017). Analisis Pengaruh Motivasi Dan Disiplin Terhadap Kinerja Guru (Studi Kasus di SMA Negeri 1 Pamijahan Kabupaten Kabupaten Bogor). Prosiding Seminar Nasonal STKIP Muhammadiyah Bogor. 1 (1), 342-357

[29] Oemar Hamalik, (1991) Pendidikan Guru Konsep Strategi, (Bandung: Mandar Maju), h.172.

[30] Hamzah Uno, (2008). Profesi Kependidikan, Jakarta: Bumi Aksara.

[31] Admin, (2008), Menuju Guru yang Profesional dan Berkualitas, (http://www Menuju Guru yang Profesional dan Berkualitas.html: Kamis, 24 April 2008, 07:19:17).

[32] Sugiyono, (2001). Statistik untuk Penelitian. Bandung: Alfabeta.

[33] Sulfemi, Wahyu Bagja dan Lestari, Ayu Hopilatul. (2017). Korelasi Kompetensi Pedagogik Guru dengan Prestasi Belajar Mata Pelajaran IPS Di SMP Muhammadiyah Pamijahan Kabupaten Bogor. Edutecno. 16 (1), 1-16. 